Nikita Khrushchev and the

Creation of a Superpower 


\title{
Nikita Khrushchev
}

\author{
AND THE \\ CREATION OF A \\ SUPERPOWER
}

\section{Sergei N. Khrushchev}

Translated by

Shirley Benson

Foreword by

William Taubman

Annotations by

William C. Wohlforth 


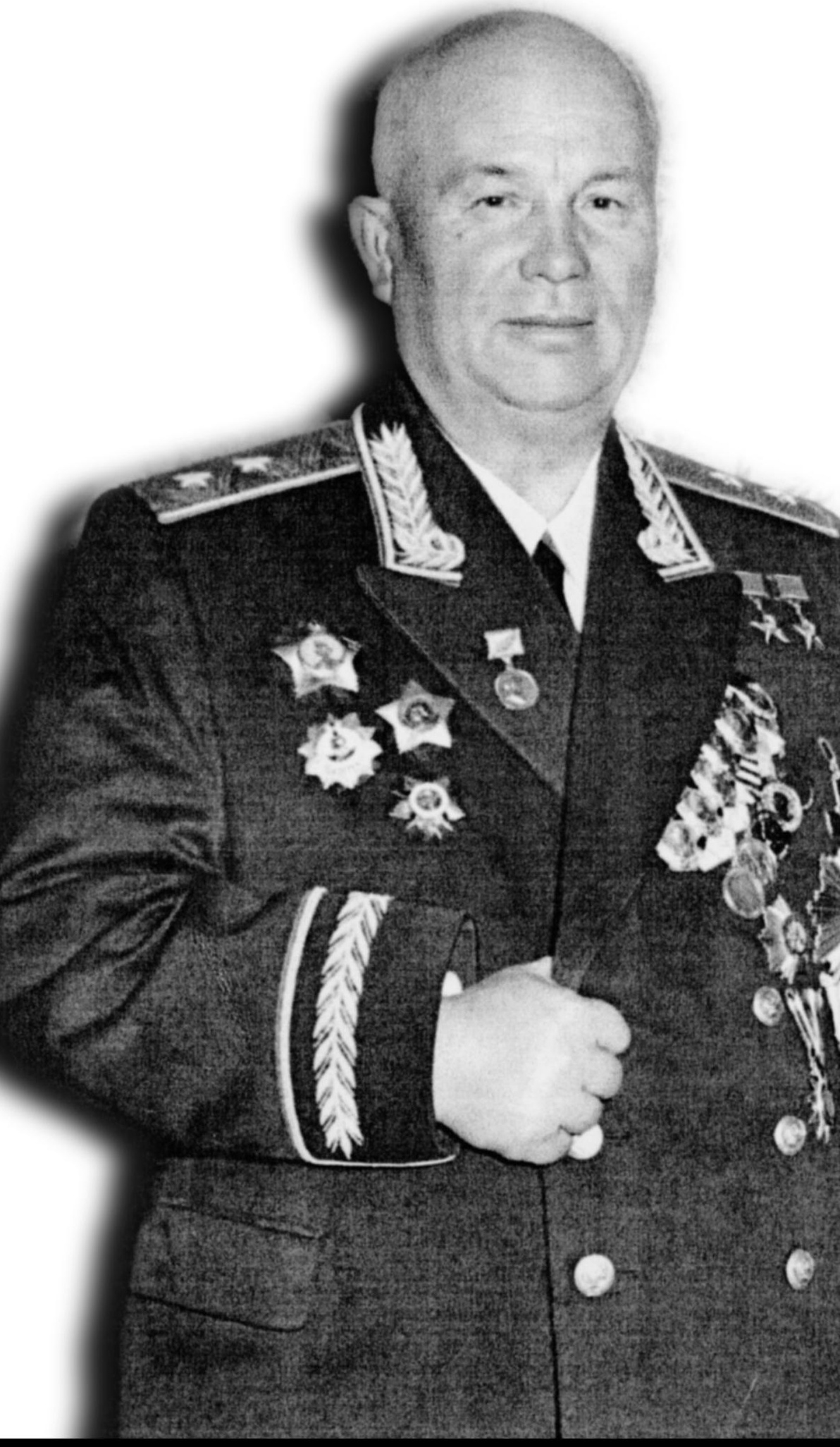


Library of Congress Cataloging-in-Publication Data

Khrushchev, Sergeř.

[Nikita Khrushchev. English]

Nikita Khrushchev and the creation of a superpower / Sergei N. Khrushchev.

p. $\mathrm{cm}$.

Abridged and translated from: Nikita Khrushchev : krizisy i rakety.

Includes bibliographical references and index.

ISBN 0-271-01927-1 (alk. paper)

1. Khrushchev, Nikita Sergeyevich, 1894-1971. 2. Heads of state-Soviet Union-Biography. 3. Soviet Union-

Politics and government-1953-1985. 4. Khrushchev, Serger. 5. World politics-1945- I. Title.

DK275.K5K4874213

947.08-dc21

CIP

Second printing, 2000

Copyright (C) 2000 The Pennsylvania State University

All rights reserved

Printed in the United States of America

Published by The Pennsylvania State University Press,

University Park, PA 16802-1003

It is the policy of The Pennsylvania State University Press to use acid-free paper for the first printing of all clothbound books. Publications on uncoated stock satisfy the minimum requirements of American National Standard for Information SciencesPermanence of Paper for Printed Library Materials, ANSI Z39.48-1992. 